
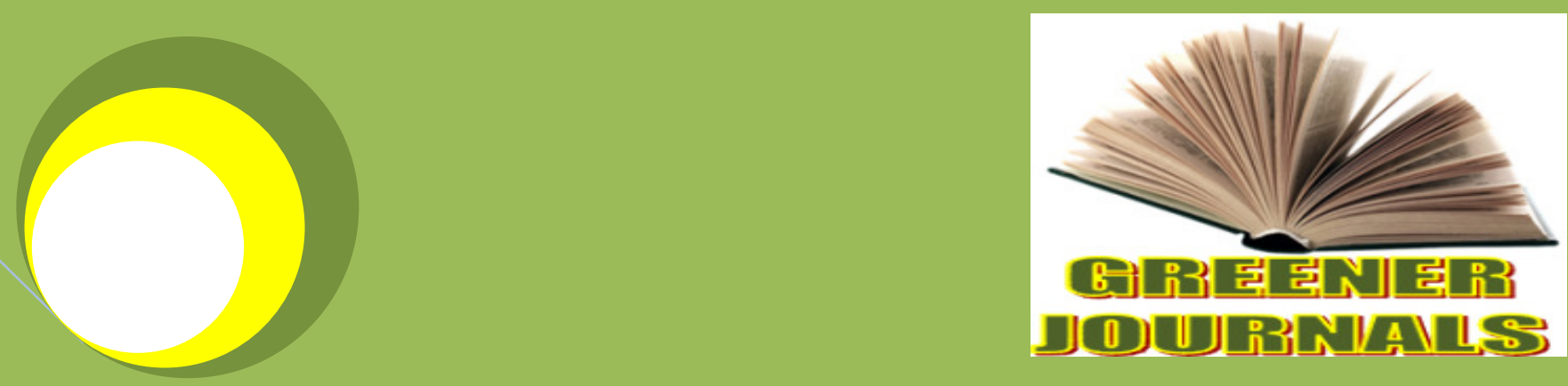

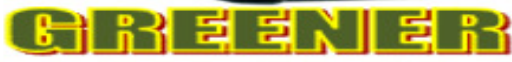
D(0) UV]

Greener. Journal of Biólogical Sciences ISSN: 2276-7762 ICV 2012: 5.99

\title{
Comparative Anatomical and \\ Palynological Studies \\ on Rumex L. species \\ (Polygonaceae) in NE \\ Iran
}

By

Mahla Soleimani

Azarnoosh Jafari

Khadijeh Nejad Shahrokhabady Dorrieh Amiri Moghadam 


\title{
Comparative Anatomical and Palynological Studies on Rumex L. species (Polygonaceae) in NE Iran
}

\author{
${ }^{1}$ Mahla Soleimani, ${ }^{1 *}$ Azarnoosh Jafari, \\ ${ }^{1}$ Khadijeh Nejad Shahrokhabady and ${ }^{2}$ Dorrieh Amiri Moghadam
}

\author{
${ }^{1}$ Department of Biology, Faculty of Sciences, Mashhad Branch, Islamic Azad university, Mashhad, Iran. \\ Rahnamaei 26 st. \\ ${ }^{2}$ Department of Biology, Faculty of Sciences, Ferdowsi University of Mashhad, Iran.
}

*Corresponding Author's Email: azarnoosh_djafari@mshdiau.ac.ir, Tel: 00985118435050

\begin{abstract}
In present study, anatomical and palynological characters of Rumex species in NE Iran were examined. For anatomical study, manual cross sections of fresh and dried stems and leaves were prepared and stained by differential staining. In palynological study, the pollen were extracted from anther, acetolysed and observed by SEM. The results of anatomical research showed, annular collenchymous tissue below the epidermis layer, different shape of vascular bundle, sclerenchymous strands around the vascular bundles in stem, dorsi-ventral mesophyll and continuous and discontinuous vascular bundles in leaves. The palynological findings indicated, panporate, tricolporate, tetracolporate, granulate, microechinate and punctate pollen in studied species.
\end{abstract}

Keywords: Anatomy, Iran, pollen, Polygonaceae, Rumex.

\section{INTRODUCTION}

The genus Rumex L. belongs to the family Polygonaceae and the order Caryophyllales which has about 200 species distributed in temperate regions, European countries, America, Asia and Australia continents (Heywood, 1978; Qaiser, 2001; Sanchez and Kron, 2008; Chase and Reveal, 2009). This genus comprises around 28 and 8 species in Iran and Khorassan Razavi Province (NE Iran) respectively (Rechinger, 1968). Rumex has antioxidant, antimicrobial and viral, anti-cancer activities and decreases blood sugar and cholesterol level (Jildirim et al., 2001; Cos et al., 2002; Ferreres et al., 2006; Sedaghat et al., 2010; Harshaw et al., 2010). Despite many reports about medicinal characteristics of this genus, internal structure and pollen studies have been done on a few Rumex species e.g. The anatomy of Rumex with special reference to the morphology of the internal bundles and the origin of the internal phloem in Polygonaceae (Joschi, 1936),Comparative anatomy of the leaves of Rumex in Jiangxi ( Li et al., 2008), anatomical study of some medicinal plants of family Polygonaceae (Hameed et al., 2010), Stem anatomy of medicinally important Rumex hastatus D. Don (Polygonaceae) (Sahney and Vibhasa, 2012) and Taxonomic implications of pollen morphology of seven species of Rumex L. from Pakistan (Yasmin et al., 2010). Whereas, comparative anatomical and palynological studies have not been done on Iranian Rumex species, this report focused on the above research to recognize variation in internal structure and pollen micromorphological features among the five Rumex species in NE Iran.

\section{MATERIALS AND METHODS}

For anatomical study of vegetative organs, the base of stem and mature leaves from five species i.e. $R$. crispus L., $R$. dentatus L., $R$. tuberosus L., $R$. chalapensis Mill. and $R$. conglomeratus Murr. were fixed in FAA solution, then manually cross sections were made and stained by green methyl and carmine then observed by different magnification of light microscopy Labomed model CMZ4. The localities of studied specimens were presented in Table.1. Some anatomical characters such as the number of collenchymous layer below the epidermis tissue, the position of secretory ducts in cortex, the shape of phloem bundles, the number and type of sclerenchymous bundles above the phloem were analyzed. 
Table 1: The locality of studied species of Rumex

\begin{tabular}{|c|c|}
\hline Species & Locality \\
\hline R. crispus & $\begin{array}{l}\text { TorbateHeydarieh, Roud Majan, } 1688 \text { m, Soleimani, } 9152 \text { (IAUM); } \\
\text { Quchan, Fatamehkhanom mount, } 2200 \text { m, Faghihnia and Zangouei, } \\
29399 \text { (FUMH); Fariman, Chehar ta Gav, 1700- } 2000 \text { m, } 11313 \\
\text { (FUMH); Trogh, Torogh dam, } 1280 \text { m, Soleimani, } 9153 \text { (IAUM); } \\
\text { Chenara, Ferizi, northern slope of dahaneh, } 1890 \text { m, Emadzadeh and } \\
\text { Memariani, } 36380 \text { (FUMH). }\end{array}$ \\
\hline R. tuberosus & $\begin{array}{l}\text { Chenaran, Dahane Jaji, } 1900 \mathrm{~m} \text {, Soleimani, } 9165 \text { (IAUM); East of } \\
\text { Quchan, Emarat mount, } 1800 \mathrm{~m} \text {, } 27459 \text { (FUMH); Kalate Nader, } \\
\text { Khanzo, Ortekan village, } 1550 \mathrm{~m} \text {, Faghihnia and Zangouei, } 24144 \\
\text { (FUMH); Dargaz, Tandoureh, } 1750 \mathrm{~m} \text {, Hojat and Zangouei, } 39377 \\
\text { (FUMH). }\end{array}$ \\
\hline R. dentatus & Torbat Heydarieh, Roud Majan, 1680 m, Soleimani, 9157 (IAUM) \\
\hline R. chalpensis & $\begin{array}{l}\text { Neyshabour, Kharv, } 1460 \mathrm{~m} \text {, Soleimani, } 9150 \text { (IAUM); Bajestan, } \\
\text { Tangolsenjedak, } 1400 \mathrm{~m} \text {, Hojat and Zangouei, } 28414 \text { (FUMH); } \\
\text { Kashmar, Ghaleh Jough, } 1300 \mathrm{~m} \text {, Hojat and Zangouei, } 28870 \text { (FUMH); } \\
\text { Ferizi, } 1650 \mathrm{~m} \text {, Soleimani, } 9148 \text { (IAUM); Birjand, between Taghiabad } \\
\text { and Roud Kaj, } 1800 \mathrm{~m} \text {, Faghihnia and Zangouei } 30146 .\end{array}$ \\
\hline R. conglomeratus & $\begin{array}{l}\text { Noghondar to Kang village, } 1330 \mathrm{~m} \text {, Soleimani, } 9155 \text { (IAUM); Ferizi, } \\
1700 \mathrm{~m} \text {, Aiatolahi and Joharchi, } 13551 \text { (FUMH); Golmakan, Kalate } \\
\text { Asheghan, } 1500 \mathrm{~m} \text {, Rashed and Aiatolahi, } 13390 \text { (FUMH }\end{array}$ \\
\hline
\end{tabular}

For palynological study, the pollen grains of $R$. crispus, $R$. conglomeratus and $R$. tuberosus were extracted from the anther and dehydrated by Glacial Acetic Acid, then acetolised, and studied by SEM and LM (Erdtman, 1960; Moore et al., 1991). Pollen characters of $R$. dentatus and $R$. chalapensis was adapted from Yasmin's et al. (2010) report. Some characteristics like: $\mathrm{P}$ (polar axis length), $\mathrm{E}$ (equatorial axis length) and the P/E ratio were measured at magnification 5000, 20000. The pollen terminology in general followed Punt et al. (2007).

\section{RESULTS}

Anatomical results of stem, revealed uni-seriate epidermis layer, collenchymous tissue, parenchymous tissue including secretory duct, sclerenchymous bundles which surround vascular bundles and vascular bundles with different shapes. The shape of sclerenchymous strands and phloem bundles, the number of collenchymous and sclerenchymous tissues varied among the studied species (Table 2, Figures. 1A- E). All the studied species had parenchymous pith except $R$. dentatus had hollow pith in stem. Also, internal vascular bundles were observed in $R$. crispus. Druse crystals were perceived in the cortex and pith of $R$. dentatus stem. In the leaf cross section of studied species, dorsi-ventral mesophyll was noticed. The palisadic parenchyma in $R$. tuberosus and $R$. crispus was biseriate while in the rest of species was uni-seriate. Also the ratio of palisadic to spongy parenchyma was variable among the species (Table 2, Figure 1F).

Table 2: The stem and leaf anatomical characters in studied species of Rumex

\begin{tabular}{|c|c|c|c|c|c|c|}
\hline Species & $\begin{array}{c}\text { The number of } \\
\text { collenchymous } \\
\text { layer }\end{array}$ & $\begin{array}{l}\text { The number of } \\
\text { sclerenchymous } \\
\text { layer }\end{array}$ & $\begin{array}{l}\text { The shape of } \\
\text { sclerenchymous } \\
\text { bundles above } \\
\text { the phloem }\end{array}$ & $\begin{array}{c}\text { The shape of } \\
\text { vascular } \\
\text { bundle }\end{array}$ & $\begin{array}{l}\text { The number of } \\
\text { Palisadic } \\
\text { parenchyma } \\
\text { layer }\end{array}$ & $\begin{array}{l}\text { The ratio of } \\
\text { Palisadic to } \\
\text { spongy } \\
\text { parenchyma }\end{array}$ \\
\hline R. crispus & 2- 3 & 6- 8 & $\begin{array}{c}\text { Circular cap } \\
\text { shaped }\end{array}$ & $\begin{array}{l}\text { Oblong } \\
\text { elliptical }\end{array}$ & 2 & 1.06 \\
\hline R. tuberosus & 4- 5 & 4- 5 & $\begin{array}{c}\text { Narrow crescent } \\
\text { shaped }\end{array}$ & Triangular & 2 & 1.32 \\
\hline$R$. dentatus & 4- 6 & $2-3$ & $\begin{array}{c}\text { Narrow crescent } \\
\text { shaped }\end{array}$ & $\begin{array}{l}\text { Obovate with } \\
\text { different size }\end{array}$ & 1 & 1.16 \\
\hline R. chalpensis & $2-3$ & $2-4$ & $\begin{array}{l}\text { Crescent shaped } \\
\text { to rectangular }\end{array}$ & $\begin{array}{l}\text { Obovate- } \\
\text { oblong } \\
\text { elliptical }\end{array}$ & 1 & 0.76 \\
\hline $\begin{array}{l}R . \\
\text { conglomeratus }\end{array}$ & $2-3$ & 3- 6 & $\begin{array}{l}\text { Broad crescent } \\
\text { shaped }\end{array}$ & $\begin{array}{l}\text { Triangular- } \\
\text { obovate }\end{array}$ & 1 & 0.86 \\
\hline
\end{tabular}


Palynological results showed tricolporate, tetracolporate, panporate and spherical- triangular pollen in polar view. The ornamentation was observed porate- punctuate to granulate (Figures $1 \mathrm{G}-\mathrm{L}$ ). The P/E ratio and quantitative features were presented in Table 3.

Table 3: Pollen characters in studied species in Rumex

\begin{tabular}{|c|c|c|c|c|c|}
\hline Species & $\begin{array}{c}\text { The shape of } \\
\text { pollen in polar } \\
\text { view }\end{array}$ & $\begin{array}{l}\text { The } \\
\text { ornamentation of } \\
\text { exine }\end{array}$ & $P$ & $\mathrm{E}$ & $\mathrm{P} / \mathrm{E}$ \\
\hline R. crispus & Panporate & microechinate & 18.27 & 16.22 & 1.12 \\
\hline R. tuberosus & Tricolporate & $\begin{array}{l}\text { Perforate- } \\
\text { echinate }\end{array}$ & 16.78 & 15.02 & 1.11 \\
\hline R. dentatus & tetracolporate & Granulate & 28.4 & 27.6 & 1.02 \\
\hline R. chalpensis & tetracolporate & $\begin{array}{l}\text { Porate- } \\
\text { punctuate }\end{array}$ & 27 & 25.4 & 1.06 \\
\hline R. conglomeratus & Tricolporate & microechinate & 23.89 & 22.43 & 1.06 \\
\hline
\end{tabular}

\section{DISCUSSION}

In anatomical analysis of stem, the minimum and maximum number of collenchymous layer below the epidermis tissue were noticed in $R$. crispus (2- 3 layered) and $R$. dentatus ( $4-5$ layered). Also the minimum and maximum number of sclerenchymous strands around the vascular bundles were observed in $R$. dentatus (2- 3 layered) and $R$. crispus (6- 8 layered) respectively. Oblong elliptical bundles was just perceived in $R$. crispus while, in the rest of studied species triangular-obovate bundles were observed. Just $R$. tuberosus had sclereid above the phloem and no secretary ducts. Just $R$. dentatus had hollow pith and $R$. crispus had internal vascular bundle. Joshi pointed that most of the species of Rumex showed presence of internal bundles. Also, absence of internal bundles has been reported in $R$. dentatus by Joshi (1936). Joshi believes "the perennial species of Rumex which are without internal bundles are the oldest forms of the genus. From these have arisen the perennial forms with internal bundles and the annual forms without internal bundles". Thus all studied species in this research except $R$. dentatus represented the oldest forms of Rumex. Sahney and Vibhasa (2012) in anatomical studies on Rumex hastatus, mentioned "Rumex hastatus is similar to $R$. dentatus but differs from it due to presence of chlorenchyma below the furrows, tannin filled cells below the chlorenchyma and large druses in particular position in the cortex and absence of hollow pith. In $R$. hastatus, internal vascular bundles were formed below the collenchymous between the first formed bundles, though in $R$. crispus internal vascular bundles forms exactly below the older ones. In leaf anatomy of seven species of Rumex L. of Jiangxi, the shape of epidermal cells, stomata apparatus, glands arrangement, the shape and the number of vascular bundle of midrib were assessed by Li et al. (2008). They explained "comparative anatomy study of leaves might provide some helps to the study of phylogeny and classification of Rumex L."The palynological results of present research, showed tricolporate, tetracolporate, panporate type while the shape of pollen in polar view was the same in three species i.e. spherical- triangular. Also, the exine ornamentation was observed microechinate, porate- punctuate to granulate. Yasmin et al. (2010) reported, "tricolporate and tetracolporate, radially symmetrical and isopolar pollen in Rumex species. Moreover, tectum was granular and perforate-punctate in $R$. dentatus and $R$. chalepensis respectively". In Yasmin's et al. research, three distinct pollen types were introduced on the basis of exine ornamentation i.e. Chalepensis type (Perforate-punctate tectum), Dentatus type (granulate tectum) and Acetosa type (coarsely reticulate tectum). According to the above types, $R$. crispus and $R$. conglomeratus fall into Dentatus type and $R$. tuberosus fall into Chalepensis type. Based on Yasmin's et al. study, "there is quite considerable variation in pollen morphology especially; exine and its sculpturing under SEM is of real systematic value and make the pollen grains decidedly distinct structures which can be employed for the delimitation of closely related species" (Yasmin et al., 2010). But in present research, differences in anatomical and pollen structures are not significant features to identify studied species. 

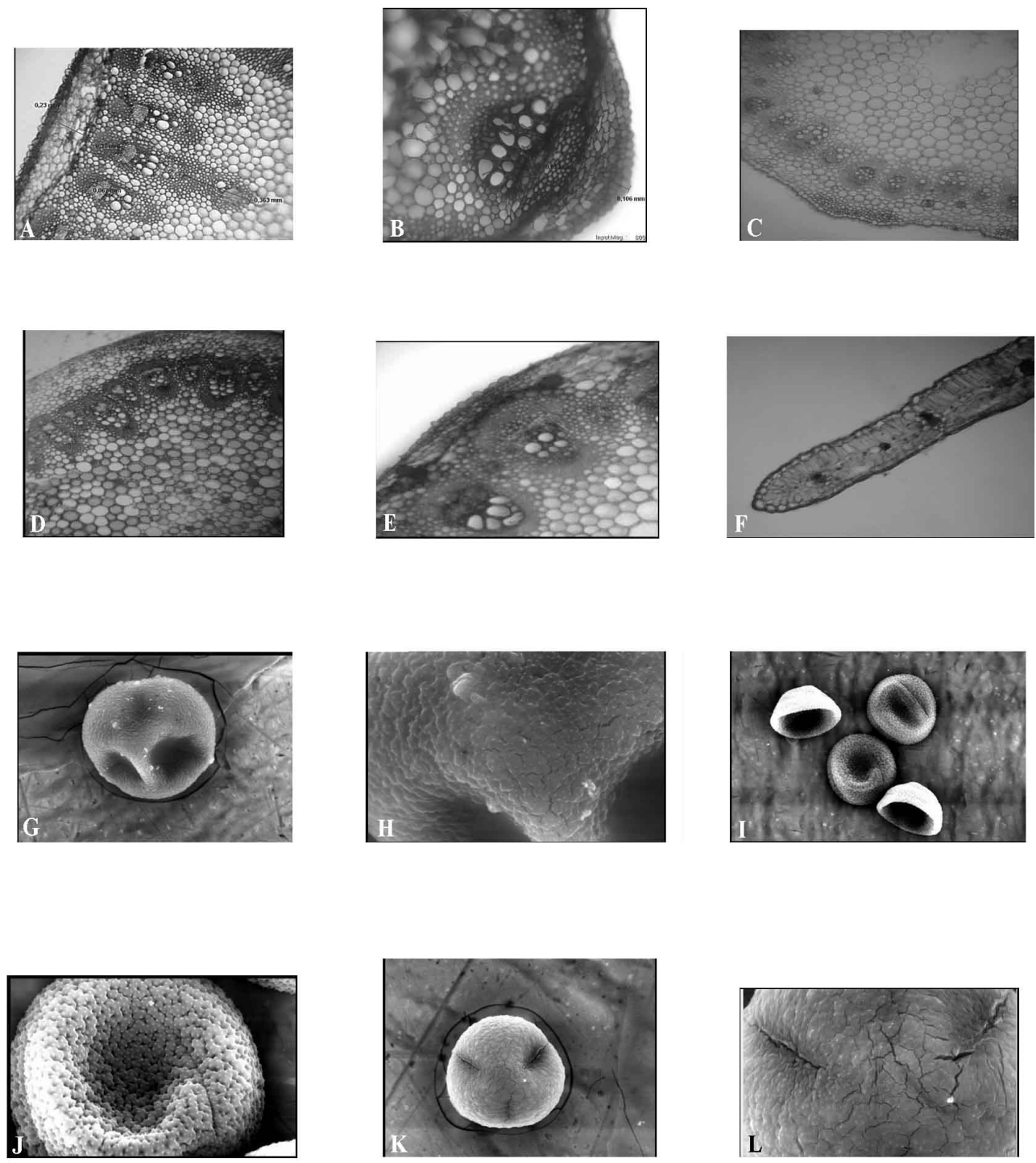

Fig. 1.

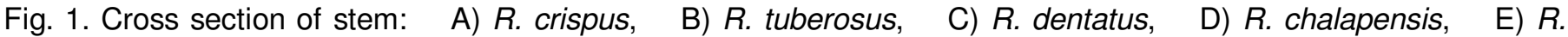
conglomeratus, F) Cross section of leaf of $R$. crispus; The pollen shape in polar view $\times 5000$ and exine ornamentation ×20000: G,H) R. crispus, I, J) R. tuberosus, K, L) R. conglomeratus.

\section{REFERENCES}

Chase, M. and Reveal, A. (2009), "An update of the Angiosperm Phylogeny Group classification for the orders and families of flowering plants: APG III", Bot. J. Linn. Soc. 161 (2): 105-121.

Cos P. Hermans N. De Bruyne T. Apers S. Sindambiwe J.B. Witvrouw M. De Clercq E. Vanden Berghe D. Pieters L. and Vlietinck A.j., 2002. Antiviral activity of Rwandan medicinal plants against human immuno deficiency virus type-1 (HIV-1). Phytomedicine 9: 62-6.

Erdtmann, G. (1960), Theacetolysis method, revised description. Svensk BotaniskTidskrskrift., 54:561-564

Ferreres F. Ribeiro V. Gil Izoquierdo A. Rodrigues M.A. Seabra R.M. Rade P.B and Valentao P., 2006. Rumex induratus leaves: interesting dietary source of potential bioactive compounds. J. Agric. Food Chem. 54: 57825789. 
Hameed I. Hussain F. and Dastagir G., 2010. Anatomical Studies of Some Medicinal Plants of Family Polygonaceae. Pak. J. Bot. 42(5): 2975-2983.

Harshaw D. Nahar L. Vadla B. Saif-e-Naser G and Sarker S., 2010. Bioactivity of Rumex obtusifolius (Polygonaceae). Arch. Biol. Sci. Belgrade 62(2): 387-392.

Heywood V.H., 1978. Flowering Plants of the World, Oxford University Press Oxford: 336 pp.

Jildirim A. Mavi A. and Aydankara Ay, 2001. Determination of antioxidant and antimicrobial activities of Rumex crispus L. extract. J. Agric. Food Chem. 49(8):4083-4089.

Joschi, A. C. 1936. The Anatomy of Rumex with special reference to the morphology of the internal bundles and the origin of the internal phloem in the Polygonacee. Am. J. Bot. 23(5): 362-369.

Li B. Zhang W.G. Chen Sh.F. Yang S.G, 2008. Comparative Anatomy of the Leaves of Rumex in Jiangxi J. Wuhan Bot. Res. 26(5): 443- 449.

Moore P. Webb J. and Collinson M., 1991. Pollen analysis $\left(2^{\text {nd }}\right.$. ed). Blackwell Science Publisher, Oxford, 216 pp.

Punt W.P. Hoen P. Nilsson S. and Thomas L., 2007. Glossary of Pollen and Spore Terminology. Rev. Paleobot. Palyno., 143: 1-81.

Qaiser M. 2001. Polygonaceae. In: Flora of Pakistan. (Eds.): Ali S.I. and Qaisar M., Department of Botany, Karachi University and Missouri Botanical Garden, St Louis, Missouri, U.S.A. 205: 110-124.

Rechinger K., 1968. Polygonaceae. In: Rechinger K. Schlman-Czeika H., (eds.) Flora Iranica, Graz-Austria. 56:2-24.

Sanchez I. and Kron K.A. 2008. Phylogenetics of Polygonaceae with an emphasis on the evolution of Eriogonoideae. Systemaic Botany 33(1): 87-96.

Sedaghat R. Roghani M. Ahmadi M. and Ahmadi F., 2010. Anti hyperglycemic and anti hyperlipidemic effect of Rumex patientia seed preparation in streptozotocin-diabetic rats, pathophysiology Elsevier science.

Sahney M and Vibhasa., 2012. Stem Anatomy of Medicinally Important Rumex hastatus D. Don (Polygonaceae). Res. J. Agric. Biol. Sci. 8(2): 154-157.

Yasmin Gh. Ajab Khan M. Shaheen N. Hayati M.Q. Ali S. and Abbas Sh., 2010. Taxonomic implications of pollen morphology of seven species of Rumex L. from Pakistan. Pak. J. Bot. 42(3): 1435-1442. 